ISBN 978-81-933894-1-6

International Conference on Arts, Social Sciences, History and Interdisciplinary Studies

(ASSHIS-2017)

Kyoto (Japan) April 20-21, 2017

\title{
Transformation of Role and Function of the Pesantren (Islamic Boarding School) in Indonesia
}

\author{
Yulasteriyani $^{1}$, Hudha Abdul Rohman ${ }^{2}$ \\ ${ }^{1}$ Faculty of Social and Political Sciences, University of Padjadjaran, Bandung, Indonesia \\ teriyaniyulas@gmail.com \\ ${ }^{2}$ Faculty of Humanities, University of Padjadjaran, Bandung, Indonesia \\ hudhud.ok@gmail.com
}

\begin{abstract}
The pesantren (Islamic Boarding school) as one of the educational institution plays an important role in improving the quality of human life. Development of pesantren in Indonesia proves that Islamic based formal education growing rapidly and much sought after by residents in Indonesia. Modernization and globalization causes transformation in pesantren in Indonesia that cause changes in a variety of roles and functions. This research focuses on the changing roles and functions of the pesantren in Indonesia are seen from various fields. Phase analysis of this research are to describe the phenomenon of the transformation of the traditional pesantren to a modern pesantren as well as describe the function and role of religious schools in the development of the quality of human resources in Indonesia. The method used library research and the data analyzed descriptively. This has become a social phenomenon that is interesting to be examined because the pesantren was instrumental in forming the character of a community in Indonesia. The Pesantren institution able to thrive in a variety of sectors field that are sector of education, economics, social, and charity. In this research obtained a summary of the role and the function of the changes from a pesantren that are the role and the functions of the Da'wah of Islam, the role and functions in human empowerment, as well as the role and the function of social culture in Indonesia society. This proves that the pesantren in Indonesia are experiencing changes in the function and role which followed the times but will not leave the function and role of Islamic.
\end{abstract}

Keywords: Modernization, Transformation, Education, Islamic Studies, and Pesantren (Islamic Boarding School).

\section{Introduction}

The pesantren has been playing an important role in developing human resources, along with its great history shows that pesantren has contributed in Indonesia civilization. As Said explains that pesantren is the oldest Islamic formal education in Indonesia. The development of pesantren historically has been taking part of the Indonesian national revolution. The pesantren has proven its existence to be the dynamism in every process of the national revolution and developing Indonesia. It is not only limited to the institution of formal education but also as social, economic, spirituality, religion and dawah institution (Said, 2011).

A word of cottage comes from Arabic letter funduq which means a bed, a cottage or a dormitory because the cottage is a simple place to accommodate students (Dhofier, 1985). Since its establishment in the 13 century, pesantren has been actively playing a fundamental role in dawah agenda or spreading Islamic education in Indonesia. The beginning of pesantren was a formal education for those who learnt about Islam as Dholfier argues that 'those basic elements are the pondok (dormitories), the mosque, the study of classical Islamic books (texts), the santri (students), and the kyai (religion figure) (Dhofier, 1980)'”. 
As the time goes by, pesantren adapts itself with modern world and globalization, the traditional pesantren has turned into a modern pesantren. Pesantren modernization is a process of cultivating values in pesantren education system and changing the old values which are irrelevant these days with the better values. The renewal of pesantren education system does not occur itself but it has to be innovation (Muiz, 2017). The transformation of pesantren is to transform the system and the structure of pesantren so that a modern pesantren can be functional in cultivating sustainable development in Indonesia.

Based on the statistic from directorate general of Islamic education in 2011 shows that there are 24.000 pesantren spreading in Indonesia. The growth of pesantren is rapidly turning into modernization. The transformation in all aspects makes people enthusiasm to invest their children in education, social, economic, cultural and politic. No wonder the stakeholders in the peace action of 211 and 411 in suing the governor of Jakarta Basuki Cahaya Purnama for the case of defamation religion were led by the ulama and kyai, in the meantime they are the output of Islamic education institution such as pesantren.

One of the modern pesantren in Indonesia which has a great contribution in developing nation is Daarut Tauhid Pesantren (DT) in Bandung (West Java). The Daarut Tauhid Pesantren was established by K.H. Abdullah Gymnastiar as known as AA Gym in September 4, 1990. Daarut Tauhid Pesantren is one of the functional pesantren in performing dawah, education, empowerment, social, culture, economic and politic. Here it is few institutions and programs of Daarut Tauhid Pesantren that are functional in the social and cultural system which spreads in all over the world. The institutions are affiliated to Daarut Tauhid: SMK (High School), Dompet Peduli Umat (DPU) Daarut Tauhid (Charity Foundation), Daarut Tauhid Pesantren Jakarta, Pusat Pengembangan Wakaf Daarut Tauhid (Central Wakf Council), and Junior High School (SMP) Daarut Tauhid.

Programs are managed by Daarut Tauhid Pesantren which are: Santri mukim Akhlak Plus Wirausaha (APW) (boarding school and entrepreneurship program for students), Program Pesantren Mahasiswa (PPM) (Student Pesantren Program), Privat Dirosah Islamiah (Islamic course for the convert), Program Masa Keemasan (PMK) (Golden Age Program), Program Dauroh (qolbiyah), Islamic Daycare Daarut Tauhid, Hajj and umroh, Pembekalan Jelang Nikah (PJN) (briefing before marriage), Pesantren Dauroh Ramadhan (DR), Pesantren kilat (short term boarding school), Santri mukim Dauroh Qolbiyah (DQ), and Santri Siap Guna (SSG).

The institution of Daarut Tauhid evolutionary has transformed and administrated. It begins with establishing the cottage cooperative pesantren of Daarut Tauhid (Kopontren) in 1994 and MQ cooperation or the Management Qolbu firm in 2002. The three organizations (The Daarut Tauhid Pesantren, Kopontren, the Management Qolbu firm) are a separated organization but, they belong to one single person KH. Abdullah Gymnastiar (AA Gym).

As a business entity, kopontren stir in two ventures which are service and trade products such as Super Mini Market (SMM), Cottage \& Cafeteria Daarul Jannah, Baitul Mal Wal Tamwil (BMT), Education \& Training Sharia Economic, and Global Servis Provider (PT. GSP). The MQ firm is the holding company that embraces unit venture such as The Madinatussalam firm as the management of MQFM, The Management Qolbu Television firm as the management of studio production and local television MQTV, MQ Consumer Goods as the management of trading for daily needs (bottle water), and MQ Tours and Travel as the service of hajj and umrah.

This study is descriptive with a qualitative approach so that it can easily analyze the phenomenon of the transformation of role and function of pesantren very deep. Data are collected by literature study. It gathers data secondary such as the website of Daarut Tauhid Pesantren, regulation, journal, book and other resources relate to transformation role and function of pesantren in Indonesia. These steps consist of data collection, reduction data, display data, and conclusion. 


\section{Discussion}

\subsection{Transformation of Traditional Pesantren to Modern Pesantren}

As we have explained before that then the main component of pesantren only consisted of santri (students), mosque, cottage, kyai and Islamic classic books. At the beginning, pesantren was limited on informal education institution which focused on Islamic study. As Fadhilah reveals that generally, pesantren consists of five elements which are santri (students), mosque, cottage, kyai and teaching Islamic classic books. These five elements are the particular characteristic that belongs to Daarut Tauhid Pesantren and differs pesantren with other education institution (Fadhillah, 2011).

Besides as informal education institution, pesantren has also an important role in the Indonesian national revolution. Benda (1983) exposes that Islamic history in Indonesia was a historical widening of santri civilization and its impact on religion life, social and politic in Indonesia. Up to now, pesantren keeps playing the role as the facilitator in order to serve Indonesian to create equality, safely and prosperously nation. But, as the time passes by pesantren has been through a social and cultural change in its every system and structure. This change is not viewed as a degradation of the education system but as education innovation, so that pesantren as education institution is expected to generate religious generation who also well educated in science and technology.

Pesantren as education institution has been cultivating and applying the values of Pancasila and the constitution of 1945. Strategic Planning Department of National Education 2010-2014 embraces this concept in the paradigm of national education which is education is to develop, improve or sustainable development. This paradigm mentions that education generates good people, the human being that is grace to nature which means that man can fulfill the needs who pays attention to the needs of generation nowadays and the next generation (sustainable intergenerational). This paradigm invites people to think about the sustainable of this planet and the whole nature (Kemdiknas, 2010).

\subsection{The Formations of Role and Function of Pesantren}

Since colonial time, pesantren was an education institution growing and developing in the middle of society, its existence has been accepted by people. Pesantren as an education institution has been contributing in an attempt to educate people, not only in morality aspect but also organizing education. As the center of religion sciences (tafaqquh fiddin), pesantren has produced many ulamas, public figures, mubalighs and religion teachers (department of religious affairs, 2003). Azyumardi Azra mentions three functions of pesantren, which are (Khusnurridlo, 2006):

a) Transmission and transfer of Islamic knowledge

b) Maintaining Islamic tradition

c) Reproduction ulama

The constitution of Indonesia number 20 in 2003 about National Education System, there are some articles stress organizing the religion education such as in 30 article verse (1) which says that: the religion education has function to prepare students to be a member of society who comprehends and apply the religion values which are believed or become the expert in religion science.

Pesantren as a functioning dawah Institute invites Muslims to exercise rights and obligations as a Muslim. In Islam there is a command to preach toward takwah to God so as a religious institution then the pesantren is present in the midst of the community to teach Islam. The transformation of the traditional pesantren to a modern pesantren causing significant changes occur dawah that are expansion dawah massively and perfectly. Pesantren Daarut Tauhid is one of a very modern pesantren professionals in the field of dawah so DT favored Indonesia in the education community as well as socio-cultural.

\subsection{The Role and Function of Pesantren in Performing Dawah}

Daarut Tauhid Pesantren, in its institution or program, has proven its existence as the institution is concerned on dawah. Daarut Tauhid as education and religion institution has applied its role and function massively to 
people around the pesantren or people generally (national and international) so that no wonder if people come to this pesantren for learning about Islam. Daarut Tauhid benefits umma so that it embodies peacefully and Islamic situation especially in the neighborhood near to the pesantren. Daarut Tauhid is categorized as modern pesantren which can be proven from its affiliation institution and program. Its dawah expansion is performed by using various dawah model which applies modern cultural rendering Daarut Tauhid more efficient and effective in actualizing God's order (dawah).

The program is categorized as dawah expansion from Daarut Tauhid Pesantren such as: SMK (High School), Program Pesantren Mahasiswa (Student Pesantren Program), Daurah Islamiah Course (Islamic course for the convert), Program Masa Keemasan (Golden Age Program), Dauroh Program (qobliyah), Pembekalan Jelang Nikah (briefing before marriage), Pesantren Kilat (short term boarding school) and Santri Mukim Dauroh Qobliyah.

The demand of dawah in Islam teaches us to keep learning since we are born until we die, no wonder if dawah program is especially for elderly so that the study of Islam in Daarut Tauhid is not only for school age. As Maryam exposes on her research about Islamic education method for elderly, it says that Pesantren Masa Keemasan (golden age program) is the most prime program from Daarut Tauhid Pesantren which is held on about 40 days. This program is only for elderly who wishes to go deep learning about Islam and getting close to Allah for achieving husnul khatimah (rest peacefully in the name of Islam) (SitiMaryam, 2014).

Another dawah expansion from Daarut Tauhid is MQTV, as television broadcast which is concerned on spreading out Islam through performing dawah so that Muslims can get too close to Allah. Mead argues in his theory that man can interact with the symbols so do people social relation on the existence of Daarut Tauhid pesantren. People mean dawah program from Daarut Tauhid positively while Daarut Tauhid responds this positive stimulus correctly. If in interaction or social relation generates positive stimulus and response then it will produce better social system and more Islamic situation in society. This sociocultural condition is going to create our founding father dream which is the equality, prosperously and safety in the society.

\subsection{The Role and Function of Pesantren in Empowering}

All The program is categorized as empowerment program from Daarut Tauhid Pesantren such as Program Santri Mukim Akhlak Plus Wirausaha (boarding school and entrepreneurship program for students), Program Pusat Pengembangan Wakaf (Central Wakf Council), Lembaga Dompet Peduli Umat (charity umma foundation) and Koperasi Pesantren Daarut Tauhid (Daarut Tauhid Cooperative Pesantren).

Lembaga Dompet Peduli Umat (charity umma foundation) is one of the large institution affiliated to Daarut Tauhid in Indonesia. This program is paid attention by the government of Indonesia in the short time since its establishment and it becomes the national zakat foundation on October 13, 2004, based on a decree of the minister of religious affairs number 410 in 2004. After becoming The National Zakat Foundation, this institution develops its branches that include 8 cities such as Jakarta, Bogor, Tasikmalaya, Garut, Semarang, Yogyakarta, Lampung, and Palembang. Besides that, it has hundred networking of empowering program from Sabang until Papua.

One of the prime empowerment programs from Charity Umma Foundation Daarut Tauhid is the misykat program, as the mustahiq organization which represents the poor. The main target of this program is the poor who has micro venture. Misykat is managed by the misykat coordinator. The coordinator is helped by the majlis assistance. The members are led by the leader of the group. Some groups join one majlis and are led by the leader of majlis (Fatoni, 2014). The charity umma foundation has grown in some cities in Indonesia and its growth optimized this empowering program. This empowerment program can compete with other zakat foundation. The expansion of Daarut Tauhid program is expected to embody its vision 'turn mustahiq into muzakki' can be accomplished very well. Indonesian whose majority religion is Islam and the duty for zakat then this program is expected to help the government in erasing the poverty which nowadays has been the main issue in a sustainable program in all over the world. 
Other empowerment programs are to empowering in economic aspect, the establishment of Daarut Tauhid Pesantren Cooperative so that it can provide vacancy job for people, in other words, Daarut Tauhid Pesantren indirectly has empowered people in socially and culturally. Baitul Mal Wat Tanwil (BMT) of Daarut Tauhid is one of the divisions under the management of Daarut Tauhid Pesantren Cooperative which has vision and mission is that maximizing and optimizing all potency of economic resources such as how Islam to face the world challenge comprehensively. To accomplish this mission, the initial strategy is 'to build and improve economic institution such as Daarut Tauhid Pesantren Cooperative which is concerned with creating professional economist basis who is strong, independent, and take sides with Muslims who are knowledgeable, comprehensive and able to look in the future' (Yani, 2015). Sociocultural process in every pesantren program and institution run based on sharia is expected to embody Daarut Tauhid's vision which is basic and philosophy in formulating "for the dhikr, fikr, ikhtiar generation".

\subsection{The Role and Function of Pesantren in Social and Cultural Aspect}

The Daarut Tauhid pesantren has really proven to people about its role and function positively as the education institution, its programs that provide a chance of study for all ages (toddler-old man). The divide of role and function of pesantren in social and cultural aspect, the researcher focuses on two programs of Daarut Tauhid which is daycare and hajj and umrah service program. Daycare Daarut Tauhid is a place for toddlers which provides a playground and fun learning, safe and sound and Islamic. This program includes moral guidance and ritualistic acts in the early through habituation such as prayer, fasting, charity, etc. As we have known that toddlers years are an age to create children personality so that day care Daarut Tauhid program which is Islamic can make the busy Muslim mothers can child care their kids.

In travel service, the Daarut Tauhid pesantren has MQ travel which is non-media venture from the management qolbu firm that provides hajj and umrah service. Not only department and ministry of religious affairs which provide hajj and umrah service in Indonesia but also pesantren as religion education institution can involve in serving people for hajj and umrah service. Indonesian's trust in using MQ travel cannot be separated from the existence of KH. Abdullah Gymnastiar (AA Gym) as the religious and public figure of Indonesia who has the power and charismatic, in addition, the service of MQ travel is effective, efficient and safety in providing a travel to Mecca. People's trust in this travel makes its vision successful as "a travel company which is qualified and has quality with tauhid (Islamic) foundation in every activity so that it benefits umma".

\section{Conclusion}

Based on the data and analysis writer, it can be concluded that transformation of pesantren (traditionalmodern) is caused by modernization and globalization. It occurs social and cultural change significantly in the system and structure of pesantren in Indonesia, however, the change renders pesantren more effective and efficient in performing the vision and mission of Islamic dawah. The proof of the effectiveness and efficiently of pesantren after transformation process are that the more easy people obtain information, deed and benefit from every program have been carried out by modern pesantren of Daarut Tauhid. The researcher also classifies three roles and functions of Daarut Tauhid Pesantren to people which are role and function in performing dawah, empowering, and social cultural function.

\section{Acknowledgements}

The author would like to acknowledge and express gratitude to the Indonesia Endowment Fund for Education (LPDP) for their support of Yulasteriyani's postgraduate research.

\section{References}

[1] Benda, H. J. Bulan Sabit dan Matahari Terbit. Jakarta, Pustaka Jaya, 1983.

[2] Dhofier, Z. The Pesantren Tradisional: A study of the Role of the Kyai in Maintenance of the Traditional Ideology of Islam in Java. Canberra, The Australian National University, 1980. 
[3] Dhofier, Z. Tradisi pesantren: Studi tentang Pandangan Hidup Kyai. Jakarta, LP3ES, $1985 .$.

[4] Fadhilah, A, "Struktur dan Pola Kepemimpinan Kyai dalam Pesantren di Jawa", Hunafa. Jurnal Studi Islamika, pp. 109, 2011.

[5] Fatoni, N, "Peran Misykat (Micro Finance Syari'ah untuk Masyarakat) DPU (Dompet Peduli Umat) Daarut Tauhid dalam Pengentasan Kemiskinan”, Economica, pp 81, 2014.

[6] Ritzer, G. Teori Sosiologi dari Sosiologi Klasik sampai Perkembangan Terakhir Postmodern, 8th ed. New York, University of Maryland, 2014, pp. 660.

[7] Khusnurridlo, M. S. Manajemen Pesantren dalam Perspektif Global. Yogyakarta, Laksbang Press, 2006.

[8] Muiz, M. N, "Rekonstruksi Pendidikan Pesantren (Studi Komparatif Pemikiran Abdurrahman Wahid dan Burcholis Madjid)", KONSTRUKTIVISME, pp 80, 2017.

[9] Said, H. A, "Meneguhkan Kembali Tradisi Pesantren di Nusantra”, Ibda' Jurnal Kebudayaan Islam, pp 178-179, 2011.

[10] Siti Maryam, E. F, “Metode Pendidikan Islam bagi Lansia di Daarut Tauhid”, TARBAWY, Vol. 1, Nomor 2, pp 176177, 2014.

[11] Yani, I, “Analisis Pengaruh Kualitas Produk, Kualitas Pelayanan, Faktor Agama, Pendidikan dan Lingkungan terhadap Custemer Satisfaction pada Produk Simpan Nikah di BMT Daarut Tauhid” Dissertation, UIN Syarif Hidayatullah., Jakarta, Indonesia, 2015.

[12] Kementerian Agama RI, "Profil Pondok Pesantren", Direktorat Pendidikan Keagamaan dan Pondok Pesantren., Jakarta, Indonesia. 2011.

[13] Kementerian Pendidikan Nasional, “ Rencana Strategis Kementerian Pendidikan Nasional 2010- 2014”, Kemdiknas, Jakarta., Indonesia. 2010.

[14] Departemen Pendidikan Nasional., "Undang-undang Sistem Pendidikan, Nomor 20 Tahun 2003”, Fokusmedia, Bandung., Indonesia. 2003.

[15] Departemen Agama, "Pola Pembelajaran di Pesantren” Ditjen Binbaga Islam, Jakarta., Indonesia. 2003.

[16] Daarut Tauhid. (February 2017). Profil Yayasan Daarut Tauhid. [Online]. Available: http://www.daaruttauhiid.org/profil

[17] Daarut Tauhid. (October 2013). Program Dompet Peduli Ummat Daarut Tauhid. [Online]. Available: http://www.daaruttauhiid.org/program/read/14/dompet-peduli-ummat-daarut-tauhiid.html

[18] Irmansyah, DT. (September 2016). Day Care Daarut Tauhid Lembaga Penitipan Anak Islami. [Online]. Available: http://www.daaruttauhiid.org/program

[19] MQ Travel. (February 2017). MQ Travel Profile. [Online]. Available: http://mqtravel.co.id/mq-travel/profil-mq-travel/ 